International Review of

Administrative Sciences

\title{
Local government strategies in the face of shocks and crises. The role of anticipatory capacities and financial vulnerability
}

\begin{tabular}{|r|l|}
\hline Journal: & International Review of Administrative Sciences \\
\hline Manuscript ID & IRAS-2018-142.R1 \\
\hline Meywuscript Type: & Articles \\
\hline Abstract: & $\begin{array}{l}\text { financial resilience, shocks, crises, anticipatory capacities, vulnerability, } \\
\text { Germany, Italy, UK, bouncing back, bouncing forward }\end{array}$ \\
\hline & $\begin{array}{l}\text { This paper, building on governmental financial resilience literature, and } \\
\text { using data from a survey of over 600 local governments in Germany, } \\
\text { different organizational response strategies (i.e., "bouncing back" vs. } \\
\text { "bouncing forward" strategies) at times of crisis. In the face of shocks, } \\
\text { higher perceived vulnerabilities will especially be associated with } \\
\text { bouncing back strategies, whereas the presence of anticipatory capacity } \\
\text { will be associated with bouncing forward strategies. }\end{array}$ \\
\hline
\end{tabular}

\section{SCHOLARONE" Manuscripts}




\section{INTRODUCTION}

In recent years, governments have faced a combination of multiple environmental shocks that have resulted in direct and/or indirect financial consequences. The relevance of these phenomena is reflected in an emerging body of research that has focused on how governments respond to crises and shocks. Most contributions in this area have described, classified and explored types of governmental responses (e.g., Kickert, 2012; Kickert and Ysa, 2014; Overmans and Noordegraaf, 2014). However, there is a relative paucity of research into the processes taking place at the micro-organizational level, i.e. of the organizational capacities, structures and systems which are (put) in place to face shocks, as well as the role played by organizational actors' perceptions in affecting responses (Weick and Sutcliffe, 2001). Similarly, whereas in the past, general management and organization literature has pointed to the importance of perceptions, sense making and anticipation in coping with shocks (Weick et al., 2005, Somers, 2009), they appear to have attracted less attention in current public sector literature.

This paper contributes to this literature by looking specifically at how governments' responses to shocks are shaped by organizational perceptions of financial vulnerabilities and the presence of anticipatory capacities, i.e., capacities that enable organizations to better recognize potential (financial) shocks before they arise (Boin et al., 2010; Lee et al., 2013; Lengnick-Hall and Beck, 2005; Linnenluecke and Griffiths, 2013; McManus et al. 2007; Weick and Sutcliffe 2001; Whitman et al., 2013).

In exploring the relationships among those variables, resilience may prove a particularly useful conceptual lens, as shown by recent studies analyzing how governments deal with the shocks and disturbances that affect their financial condition (see Barbera et al., 2015, 2017; Davoudi, 2012; Linnenlucke and Griffiths, 2010; Mamouni-Limnios et al., 2014; Shaw, 2012; Steccolini et al., 2017; Sutcliffe and Vogus, 2003). Resilience is a multifaceted concept, yet two main features have been highlighted as defining it. On the one hand, it refers to the capacity to react to crises, bouncing back to an original state (Boin et al., 2010: 8; Linnenluecke, 2017: 6; Meyer, 1982); on the other hand, it refers to the capacity to anticipate and cope with the unexpected, bouncing forward through the enhancement of, or development of new, capabilities (Meyer, 1982; Somers, 2009).

Our paper draws on the conceptual framework of governmental financial resilience developed by Barbera et al. (2017) and based on multiple case studies in three country contexts, further consolidated through the analysis of about thirty additional cases across 8 countries, 
worldwide (Steccolini et al., 2017). This framework explains how different patterns of financial resilience result from the deployment and development of internal anticipatory and coping capacities as well as their combinations and interactions with environmental conditions and perceived financial vulnerabilities.

Building on these previous qualitative findings, which identified the important role that the presence (or absence) of anticipatory capacities and perceptions of financial vulnerabilities have in shaping organisational responses to shocks, the present paper adopts a quantitative approach to explore in more depth the roles of anticipatory capacities, and perceptions about financial vulnerability. More specifically, it explores the roles played by such factors in driving and explaining different governmental responses to shocks as well as how responses are affected by the types of shocks themselves.

The research is based on a survey of German, Italian and UK local governments (LGs), the governmental level nearest to the citizens, which provide an array of 'tangible' services and thus directly affect the quality of life of those they serve. LGs have been significantly impacted by recent shocks affecting their finances. The results show that, in the face of shocks, higher perceived vulnerabilities will especially be associated with bouncing back strategies, whereas the presence of anticipatory capacity will be associated with bouncing forward strategies.

The paper is structured as follows. The next section shortly reviews extant literature and presents the conceptual framework and the underlying hypotheses. Section three describes the methods. Section four presents the results. The fifth section discusses them and draws conclusions, also highlighting the implications for practice and research.

\section{CONCEPTUAL FRAMEWORK AND HYPOTHESES DEVELOPMENT}

Our study draws on the concept of governmental financial resilience, whereby governments' ability to anticipate, absorb and react to shocks affecting their finances is the result of the interaction of environmental conditions as well as organizational dimensions (Barbera et al., 2015, 2017; Davoudi et al. 2013; Lengnick-Hall and Beck, 2005; Linnenluecke, 2017; Linnenluecke and Griffith, 2013; Nelson et al., 2007; Somers, 2009; Steccolini et al., 2017; Sutcliffe and Vogus, 2003). Such conditions and dimensions are discussed further in the subsections below, where hypotheses are advanced and the conceptual framework is presented.

\section{Responses to shocks (dependent variable)}




\section{Perceived shocks}

External shocks are events that have significant impact on organizations, sometimes even materializing the threat of organizational failure. The impact can be direct, such as eroding tax bases, or indirect, e.g. due to natural disasters or changes in government policy (see Jones et al., 2017). Although the question of whether there exist objective criteria that define when an event can be perceived as a 'triggering' event in terms of a crisis or shock, or whether the existence of a crisis or shock is determined by individual perceptions still seems to be open for debate (see Drennan et al. 2014, p. 14 ff.), several scholars highlight the key role that perceptions play in dealing with crisis and shock. In particular, they argue that individual perceptions as well as managerial interpretation of events determine how much attention is dedicated to an event or potential shock and which actions the organization takes in responding to a shock or crisis (e.g. Billings et al., 1980; Pauchant and Mitroff, 1992; Pearson and Clair, 1998; see also Daft and Weick, 1984; Dutton and Jackson, 1987; Weick, 1979). Much of the literature that has explored governmental responses to the global financial crisis shows that governments across the globe have been hit to varying degrees by the financial crisis, and that some have responded with only incremental, yet others with more fundamental, measures (see Kickert, 2012; Kickert et al., 2013; Peters, 2011). In addition, case studies of LGs in Germany, Italy as well as the UK have highlighted that changes in regulations such as taxation limitations and devolvement of tasks, or cuts to public expenditure (Barbera et al., 2017; Jones, 2017; Papenfuß et al., 2017) can have unexpected and long-lasting effects on the LGs' finances, and 
impact on public managers' perceptions and elaboration of ensuing response strategies. In line with these findings, it may be expected that when public managers perceive a stronger intensity of external shocks, this will translate in stronger responses, both in terms of incremental adaptation and buffering (bouncing back) and of more radical transformations and repositioning (bouncing forward).

H1: Higher perceptions of external shocks are associated with higher reliance on both bouncing back (Hla) and bouncing forward (H1b) strategies

\section{Vulnerability}

Vulnerability represents the level of exposure to shocks (McManus et al., 2007). Being the result of external as well as internal sources, it lies at the interface between the environment and the organization (figure 1). Qualitative analyses of LGs financial resilience have shown that it is the sense of being able to control the vulnerability and/or influence its sources that affects the way shocks are interpreted and subsequently tackled (Maher and Deller 2007, 2011; Jimenez 2012; Barbera et al., 2017), something which is also evident in other, more general, studies (see also Boin et al., 2010; Lengnick-Hall and Beck, 2005; Linnenluecke and Griffiths, 2013; Lu and Xue, 2016; McManus et al., 2007; Somers, 2009). Prior qualitative studies showed that high levels of vulnerability were associated with coping strategies that built mainly on buffering, including efforts on managing internal resources through reducing expenditure and downsizing. LGs where the sources of financial vulnerability were regarded as at arm's length and thus manageable, in contrast, exerted a more proactive behavior to shocks and an increased ability to pro-actively manage or offset the impact of environmental conditions (Barbera et al., 2017; Steccolini et al., 2017). The level of perceived vulnerability will thus be expected to have a different effect on LGs' responses, with higher perceived vulnerability being more likely to encourage defensive and risk averse approaches aimed at bouncing back, and lower perceptions of vulnerability leaving leeway for more transformative, innovative and entrepreneurial approaches. From this follows:

H2: A higher level of financial vulnerability is positively associated with bouncing back strategies (H2a), and negatively associated with bouncing forward strategies (H2b) 
Anticipatory capacities are the tools and capabilities that enable LGs to better identify and manage their vulnerabilities and recognize potential shocks before they arise. As such, they are not limited to forms of planning, monitoring or risk assessment, but are also related to the cognitive aspects of situation awareness and sense-making (e.g. Boin et al., 2010; LengnickHall and Beck, 2005; Linnenluecke and Griffiths, 2013; McManus et al., 2007; Somers, 2009). In this context, some scholars have argued that the availability or improvement of anticipatory capacities, i.e. the tools and capabilities that enable LGs to anticipate shocks and crises and better identify and manage their vulnerabilities, also assist them in (pro-actively) coping with shocks and crises (Lengnick-Hall and Beck, 2005; Somers, 2009). Anticipation allows organizations to prepare in advance for coping with shocks, exploring possible routes, including re-positioning and re-thinking of services and activities, and setting in place more comprehensive strategies to respond to them. Thus, a strongest presence of anticipatory capacities is expected to facilitate the adoption of bouncing forward strategies, but not necessarily predict the adoption of bouncing back ones. From this follows:

H3: A higher level of anticipatory capacities (i.e. monitoring, information exchange, information sharing) is positively associated with bouncing forward (H3b) but not bouncing back (H3a) strategies.

The expected effects are summarized in Figure 1.

[Figure 1: Conceptual framework]

\section{METHODS}

The research builds on a survey of LGs in Germany, Italy, and the UK, complemented by an analysis of archival data covering financial and socio-demographic aspects.

\section{The unit of analysis: local governments in Germany, Italy and the UK}

All three selected countries are large economies with LGs being responsible for a wide array of similar services including, amongst others, social protection, education, economic affairs, housing and community amenities, public order and safety and health. They represent however different administrative traditions and the number of LGs varies. This is mainly due to the relative size of the populations served by LGs in each country. In order to provide a meaningful 
basis for comparison, LGs included in the survey were identified based on a stratified sampling approach. The reference population in Italy and Germany is given by all the LGs with more than 5,000 inhabitants. ${ }^{1}$ The reference population in Italy therefore includes 2,411 units while the reference population in Germany includes 2,880 units. Given the different distribution of LGs across dimensional classes, larger LGs are less represented than smaller ones in the whole population. As a consequence, to ensure satisfactory representation of both dimensional classes as well as efficiency, all LGs with a population above 15,000 were included in the sample, i.e., 961 LGs in Germany and 737 in Italy. For LGs with a population between 5,000 and 15,000, we selected 50\% of local governments (960 LGs for Germany and 837 for Italy) considering their geographical distribution (differentiated between East and West in Germany, North and South in Italy). Based on lists which include all local governments between 5,000 and 15,000 per region, we randomly selected local governments from each region. Information on the regional distribution of the sample as well as the responses can be found in Appendix 1a and 1b. In the UK, successive structural change dating back to the 1970s has seen a reduction in the number of local government institutions servicing ever larger populations (current average population around 150,000). Except for two, all LGs exceed population figures of 15,0002 and we therefore decided to include all LGs from three of the four regions ${ }^{3}$ (a total of 406) in the survey. The questionnaire was administered online and respondents were asked to answer for their organization as a whole rather than sub-units within it. The questionnaire was sent to LGs' chief executive officers, chief financial officers and service managers (to ensure coverage of a variety of comparable public services, social services, public works, culture and leisure were taken into consideration). In general terms, the level of seniority of the respondents was chosen as it is more likely to have the required departmental/organizational wide view. The email addresses were collected from the governmental websites as they are publicly available. To ensure the highest possible response rate, at least two reminders were sent in each country. ${ }^{4}$

\footnotetext{
1 The smallest LGs (below 5,000) were excluded on the one hand to ensure to have a manageable number of responses, and on the other hand due to restrictions with regard to the accessibility of financial data for local governments with a population below 5,000 in Germany. In Italy the accessibility of e-mail addresses is a major issue. Moreover, smaller local governments (below 5,000) are generally subject to different law requirements with regard to their financial management systems, and they enjoy a specific funding system as well as support policies. ${ }^{2}$ One LG has a population lower than 5,000 and one LG falls into the range between 5,000 and 15,000. Source: Office for National Statistics 2011 Census data on population estimates for local authorities in the UK: https://www.ons.gov.uk.

${ }^{3}$ Northern Ireland was excluded from the study as the 11 local governments here were reorganised in April 2015, and as such the period under consideration was not relevant to these very recently created organisations.

${ }^{4}$ The time between sending the survey (in May 2017) and the first reminder ranged between eight days (Italy) and fourteen days (Germany). The second reminder was sent after three to four weeks (end of June). For Italy, two additional reminders were sent.
} 


\section{Operationalization of variables}

The variables discussed above and presented in figure 1 were operationalized drawing on the literature on resilience, organizational capacities, and governmental financial management, as well as the qualitative groundwork put forward by Steccolini et al. (2017). The questionnaire was developed and translated to ensure fit in the respective country contexts while preserving comparability. Appendix 2 shows how the resilience dimensions were operationalized, and table 1 and table 2 provide detailed information on the items that were used to measure each dimension.

With specific reference to shocks, the present study looks at three different shocks, which have been mentioned across LGs in eleven countries (Steccolini et al., 2017): the global financial crisis, migration ${ }^{5}$, and (change of) regulations. With regard to financial vulnerabilities, four key issues were assessed to analyze if LGs are in control of both external and internal financial vulnerability sources: financial autonomy, abundance of financial resources (fiscal slack), level of indebtedness and volatility of own revenue resources (Hendrick, 2011; McManus et al., 2007; Maher and Deller, 2011). A set of questions regarding the perceived presence of anticipatory capacities in LGs were derived from the literature (see

\footnotetext{
${ }^{5}$ In recent years, migration has posed a significant challenge to European countries, but the immigration surge in 2015 has been a shock to German local governments in particular (see Eurostat 2015).
} 
for more details appendix 2 and table 2). Responses load onto the expected three subcategories for anticipatory capacities, consisting of (1) exchange of information with external actors (e.g. upper government levels, service providers); (2) monitoring activities (e.g. national policies and regulations, citizen's needs, economic and socio-demographic developments) as well as (3) providing staff with sufficient information and fostering an organizational setting that encourages problem analysis and information sharing (table 2). The summative variables for each subcategory reported acceptable alphas, reaching Cronbach alphas higher than .7 in all cases $^{6}$.

In addition to the survey data, archival financial data and published reports were used as sources for the analysis ${ }^{7}$. We included three financial indicators- average debt level, investment ratio and current ratio - covering a ten-year period (2006-2015) as well as size as control variables. The data were analyzed by means of descriptive statistics and factor analysis. In a further step, ordinary least square regression is chosen as the statistical method to test the developed hypotheses.

\section{RESULTS}

The results of factor analyses as well as descriptive statistics are presented in tables 1 and 2. The following sub-section discusses the results of the test of hypotheses, based on the regression analysis.

The factor analysis (table 1) reveals that responses load on two different types of strategies (i.e. bouncing back and bouncing forward), which were adopted by LGs during the last five years. A summative variable of each strategy reported acceptable Cronbach alphas (0.7). As shown in table 1, LGs appear to rely more on bouncing forward than on bouncing back strategies.

\footnotetext{
${ }^{6}$ Appendix 2 shows the results of the factor analysis for Germany and Italy. Due to the low number of responses from UK local governments (64), no factor analysis was applied and we only consider them in the descriptive analysis based on identified categories. However, the Cronbach alphas for each subcategory exceed .8, therefore also pointing to a high internal reliability.

${ }^{7}$ We used Aida Pa database and the website of the Ministry of Interior that publish the main financial data for Italian LGs, based on year-end financial reports, for Italy, and in the UK Statistics Wales, Local Government Finance Statistics (Scotland) and the Department for Communities and Local Government (Statistics at DCLG England). For Germany, the database http://www.wegweiser-kommune.de/ was accessed to obtain financial data for the years 2006-2015.
} 
[Table 1]

Respondents generally gave different weights to different types of shocks (table 2) with changing regulations being perceived as most important external shocks followed by the global financial crisis. Migration, in contrast, seems to have affected local governments only to a relatively minor extent.

[Table 2]

The subsequent section explores whether and to what extent governmental responses are driven by different types of shocks and crises, financial vulnerabilities and/or by internal capacities that enable organizations to better recognize potential financial shocks before they arise. Table 3 presents the multiple regression models for the antecedents of the two types of strategies described above, i.e., bouncing back and bouncing forward. To determine whether Ordinary Least Square was appropriate, data were examined for heteroscedasticity and multicollinearity, both returning satisfying results. All models achieve good rates for multicollinearity and no Variance Inflation Factor (VIF) higher than 1.75 was reported in the models. The models offered reasonable fit for a cross-sectional design. The explained variance ranges between .20 (bouncing forward model) and .29 (bouncing back model).

[Table 3]

Table 3 shows that bouncing back and bouncing forward strategies were driven by different antecedents. While it turned out that all types of shocks show a positive association with both types of strategies, therefore supporting the hypothesis (H1) that higher perceptions of shocks are related with higher reliance on response strategies, their significance varies. Migration shows the strongest effect in the bouncing forward model while regulation shows the strongest effect in the bouncing back model. Although being significant, the effect of the global financial crisis turned out as comparatively low in both models, barely reaching significance in the bouncing back model.

The main enablers of bouncing back responses are the various sources of financial vulnerability, therefore supporting the hypothesis that higher perceived financial vulnerability will bring about bouncing back strategies $(H 2 a)$. The results also show that, as hypothesized 
$(H 2 b)$, perceived financial vulnerability has a negative association with bouncing forward strategies, but its effect is much weaker.

Moreover, the different dimensions of anticipatory capacities show a positive association with bouncing forward strategies of LGs $(H 3 b)$. However, the impacts vary, with information exchange showing the highest and information sharing showing the lowest but still significant effect. The association disappears when looking at their relationship with bouncing back strategies $(H 3 a)$.

The controls suggest that both strategies were negatively associated with a positive current ratio covering a ten-year period, while the three other controls turned out as being nonsignificant.

\section{DISCUSSION AND CONCLUSIONS}

Looking at LGs across Germany, Italy and the UK, this study explored the roles of perceptions on shocks and financial vulnerability as well as anticipatory capacities in explaining the type of strategies adopted to respond to shocks. The analysis shows that perceptions of the most important recent shocks, as well as capacities for anticipating them, and financial vulnerabilities appear to be relevant in explaining LGs' strategies in the face of shocks.

In exploring the links between external shocks, internal conditions and responses to shocks, the analysis shows that the reliance upon bouncing back and bouncing forward strategies is explained by different factors. Bouncing back strategies (e.g. deferring investments, increasing fees) are likely to be found in the presence of high levels of perceived financial vulnerability. Conversely, the adoption of bouncing forward strategies (e.g. changing service delivery, establishing new services) appears to be positively associated with the presence of strong anticipatory capacities (especially information exchange) and to be hindered by high levels of financial vulnerability. In looking at these results, it is worth noticing that the global financial crisis appears to have less explanatory power than other shocks, probably because, while remaining still relevant, its effect may be now fading away in the face of the emergence of new shocks. The association between migration and bouncing forward seems to be in line with views that the former will require an overall reconfiguration of public services, whereas the association between changes in regulations with bouncing back appears to suggest that such changes are seen as less wide-ranging and requiring less incisive interventions, or interventions that do not put into question the configuration of public services. 
Most importantly, the results highlight that perceptions of high financial vulnerability are central in explaining especially reliance on bouncing back strategies. Hence, LGs perceiving their financial conditions as being difficult will be less likely to embark on bouncing forward actions. Moreover, and conversely, they show the important role played by anticipatory capacities in explaining the adoption of bouncing forward strategies, whereas they do not appear to play a relevant role in explaining bouncing back strategies. The analysis supports previous qualitative findings, as anticipatory capacities appear to co-occur with adaptive, and transformative behavior (i.e. bouncing forward), also reducing perceived financial vulnerability, while heavy exploitation of buffering capacities may crowd out the development of other capacities needed to bounce forward, resulting in higher levels of vulnerability over time (Barbera et al., 2017; Davoudi et al., 2013; Meier and O’Toole, 2009; Wildavsky, 1988).

The study has relevant implications for managers and policy makers as the results reveal the relationship between different anticipatory capacities and perceptions of financial vulnerabilities and the strategies adopted by LGs to face shocks. While bouncing back is strongly linked to the associated vulnerabilities, the implementation of bouncing forward strategies when facing difficult times turns out as being mainly dependent on the capacities identified above. This emphasizes that, whenever willing to adopt a bouncing forward approach, it is important to develop wider anticipatory capacities within LGs as a key element to cope effectively under difficult conditions, and to build and nurture a financial resilience culture.

The present study contributed to further developing and operationalizing the dimensions of financial resilience, and more specifically anticipatory capacities and perceived financial vulnerability, understanding their relevance for LG response strategies. The results are however based on a cross-sectional research design and thus present associations. The adoption of a longitudinal perspective in future studies may offer additional insights into causal links, as well as how strategies evolve over time and under which conditions. The dimensions identified in the framework also offer LG actors the potential to better reflect on their own sources and levels of vulnerabilities and understand what anticipatory and coping capacities they need to assess, nurture, and develop in order to anticipate, absorb and react to shocks affecting their finances over time. Finally, as smaller local governments were not taken into consideration in this study, further analyses may focus on them to further explore the roles of anticipatory capacities in smaller organizations. 


\section{REFERENCES}

Amel-Zadeh A and Meeks G (2013) Bank Failure, Mark-to-market and the Financial Crisis. Abacus 49(3): 308-339.

Amniattalab A and Ansari R (2016) The effect of strategic foresight on competitive advantage with the mediating role of organisational ambidexterity. International Journal of Innovation Management 20(03): 1-18.

Andrews R (2010) Organizational social capital, structure and performance. Human Relations 63(5): 583-608.

Andrews R (2011) Exploring the Impact of Community and Organizational Social Capital on Government Performance: Evidence from England. Political Research Quarterly 64(4): 938-949.

Andrews R, Boyne GA, Law J and Walker RM (2009) Strategy formulation, strategy content and performance. Public Management Review 11(1): 1-22.

Andrews R, Boyne GA and Walker RM (2006) Subjective and objective measures of organizational performance: an empirical exploration. In: Boyne G, Meier K, O'Toole L and Walker R (eds) Public service performance: Perspectives on measurement and management. New York: Cambridge University Press, pp. 14-34.

Armstrong, J. S., and Overton, T. (1977). Estimating Nonresponse Bias in Mail Surveys. Journal of Marketing Research 15 (8): 396-402.

Arnaboldi M, Lapsley I and Steccolini I (2015) Performance management in the public sector: the ultimate challenge. Financial Accountability and Management 31(1): 1-22.

Barbera C, Jones M and Steccolini I (2015) Governmental Financial Resilience Under Austerity: The Case of English Local Authorities. CIMA Executive Summary Report 11(3).

Barbera C, Jones M, Korac S, Saliterer I and Steccolini I (2017) Governmental financial resilience under austerity in Austria, England and Italy: how do local governments cope with financial shocks? Public Management 95(3): 670-697.

Beeri I (2012) Turnaround management strategies in public systems: the impact on group-level organizational citizenship behaviour. International Review of Administrative Sciences 78(1): 158-179.

Billings RS, Milburn TW and Schaalman ML (1980) A model of crisis perception: A theoretical and empirical analysis. Administrative Science Quarterly 25(2): 300-316.

Boin A, Comfort LK and Demchack CC (2010) The Rise of Resilience. In: Comfort LK, Boin A and Demchack CC (eds) Designing Resilience. Pittsburgh: Pittsburgh University Press, pp. 1-13. 
Boyne GA (2004) A '3Rs' Strategy for Public Service Turnaround: Retrenchment, Repositioning and Reorganization. Public Money \& Management 24(2): 97-103.

Boyne GA (2006) Strategies for public service turnaround. Lessons From the Private Sector? Administration \& Society 38(3): 365-388.

Burnard K, Bhamra R and Young RI (2012). Critical factors of organisational resilience. In: Proceedings of the 19th International EurOMA Conference Amsterdam, NL, 1-5 July 2012.

Cepiku D, Mussari R and Giordano F (2016) Local governments managing austerity: Approaches, determinants and impact. Public Administration 94(1): 223-243.

Chabrak N and Gendron Y (2015) Promoting research from the "periphery": Engaging critically with the Global Financial Crisis. Critical Perspectives on Accounting 30: 1-8.

Cohen WM and Levinthal DA (1990) Absorptive Capacity: A New Perspective on Learning and Innovation. Administrative Science Quarterly 35(1) Special Issue: Technology, Organizations, and Innovation: 128-152.

Daft RL and Weick KE (1984) Toward a model of organizations as interpretation systems. Academy of Management Review 9(2): 284-295.

Davoudi, S (2012) Resilience: A Bridging Concept or a Dead End? Planning Theory and Practice 13(2): 299-333.

Davoudi S, Brooks E and Mehmood A (2013) Evolutionary resilience and strategies for climate adaptation. Planning, Practice and Research 28(3): 307-322.

Drennan LT, McConnell A and Stark A (2014) Risk and Crisis Management in the Public Sector. 2nd edition. London: Routledge.

Dutton JE and Jackson SE (1987) Categorizing strategic issues: Links to organizational action. Academy of Management Review 12(1): 76-90.

Eurostat (2015) Immigrants 2015 per 1,000 inhabitants. Available at: http://ec.europa.eu/eurostat/statistics-

explained/index.php/File:Immigrants, 2015 (per 1000 inhabitants).png (accessed 19 July 2017).

Eurostat (2016) Asylum applications (non-EU) in the EU-28 Member States, 2006-2017. Available at: http://ec.europa.eu/eurostat/statistics-explained/index.php/Asylum_statistics (accessed 19 July 2017).

Gårseth-Nesbakk L and Kjærland F (2016) Precarious Investments and Blame Gaming Adverse Effects and the Inherent Danger of Simplification. Financial Accountability \& Management 32(3): 281-308. 
Groves SM and Valente MG (1994) Evaluating financial condition: A handbook for local government', International County. Washington, DC: City Management Association.

Groves SM, Godsey WM and Shulman MA (1981) Financial indicators for local government. Public Budgeting \& Finance 1(2): 5-19.

Hendrick R (2004) Assessing and measuring the fiscal heath of local governments: Focus on Chicago suburban municipalities. Urban Affairs Review 40(1): 78-114.

Hendrick R (2011) Managing the fiscal metropolis: The financial policies, practices, and health of suburban municipalities. Washington, DC: Georgetown University Press.

Hodges R and Lapsley I (2016) A Private Sector Failure, a Public Sector Crisis - Reflections on the Great Recession. Financial Accountability and Management 32(3): 265-280.

Hofer CW (1980) Turnaround strategies. The Journal of Business Strategy 1(1): 19-31.

Jansen JP, Van Den Bosch FAJ and Volberda HW (2005) Managing potential and realized absorptive capacity: how do organizational antecedents matter? Academy of Management Journal 48(6): 999-1015.

Jaworski BJ and Kohli AK (1993) Market orientation: antecedents and consequences. The Journal of Marketing 57(3): 53-70.

Jimenez BS (2012) Strategic planning and the fiscal performance of city governments during the Great Recession. The American Review of Public Administration 43(5): 581-601.

Jones BA (2015) Benchmarking organizational resilience: A cross-sectional comparative research study. PhD Thesis, New Jersey City University, USA.

Jones M (2017) English Resilience in the Face of Austerity. In: Steccolini I, Jones M and Saliterer I (eds) Governmental Financial Resilience (Public Policy and Governance, Volume 27), Bingley: Emerald Publishing Limited, pp. 35-52.

Jones M, Saliterer I and Steccolini I (2017) Introduction: Governments and Crises. In: Steccolini I, Jones M and Saliterer I (eds) Governmental Financial Resilience (Public Policy and Governance, Volume 27) Bingley: Emerald Publishing Limited, pp.1-16.

Kickert W and Ysa T (2014) New development: How the Spanish government responded to the global economic, banking and fiscal crisis. Public Money \& Management 34(6): 453-457.

Kickert W, Randma-Liiv T and Savi R (2015) Politics of fiscal consolidation in Europe: a comparative analysis. International Review of Administrative Sciences 81(3): 562-584.

Kickert W (2012) State Responses to the Fiscal Crisis in Britain, Germany and the Netherlands. Public Management Review 14(3): 299-309. 
Lee AV, Vargo J and Seville E (2013) Developing a tool to measure and compare organizations' resilience. Natural Hazards Review 14(1): 29-41.

Lengnick-Hall CA and Beck TE (2005) Adaptive fit versus robust transformation: How organizations respond to environmental change. Journal of Management 31(5): 738-757.

Lengnick-Hall CA, Beck TE and Lengnick-Hall ML (2011) Developing a capacity for organizational resilience through strategic human resource management. Human Resource Management Review 21(3): 243-255.

Lindner, J. R., Murphy, T. H., \& Briers, G. E. (2001). Handling nonresponse in social science research. Journal of Agricultural Education 42(4): 43-53.

Linnenluecke MK (2017) Resilience in Business and Management Research: A Review of Influential Publications and a Research Agenda. International Journal of Management Reviews 19(1): 4-30.

Linnenluecke MK and Griffiths A (2013) The 2009 Victorian Bushfires: A Multilevel Perspective on Organizational Risk and Resilience. Organization and Environment 26(4): 386-411.

Lodge M and Hood C (2012) Into an Age of Multiple Austerities? Public Management and Public Service Bargains across OECD Countries. Governance: An International Journal of Policy, Administration, and Institutions 25(1): 79-101.

McManus S, Seville E, Brunsden D, and Vargo J (2007) Resilience management: a framework for assessing and improving the resilience of organisations. Report, Resilient Organisations Programme, New Zealand.

Maher CS and Deller SC (2011) Measuring municipal fiscal condition: Do objective measures of fiscal health relate to subjective measures? Journal of Public Budgeting, Accounting \& Financial Management 23(3): 427-459.

Mamouni-Limnios EA, Mazzarol T, Ghadouani A and Schilizzi SGM (2014) The Resilience Architecture Framework: Four organizational archetypes. European Management Journal 32(1): 104-116.

Meier KJ and O'Toole LJ Jr. (2009) The Dog that Didn't Bark: How Public Managers Handle Environmental Shocks. Public Administration 87(3): 485-502.

Meyer AD (1982) Adapting to Environmental Jolts. Administrative Science Quarterly 27(4): $515-537$.

Meyer RE and Hammerschmid G (2010) The Degree of Decentralization and Individual Decision Making in Central Government Human Resource Management: A European Comparative Perspective. Public Administration 88(2): 455-478. 
Mott PE (1972) The characteristics of effective organizations. New York: HarperCollins Publishers.

Nelson DR, Adger WN and Brown K (2007) Adaptation to Environmental Change: Contributions of a Resilience Framework. Annual Review of Environment and Resources 32: 395-419.

Overmans T and Noordegraaf M (2014) Managing austerity: Rhetorical and real responses to fiscal stress in local government. Public Money and Management 34(2): 99-106.

Overmans, T and Timm-Arnold, K-P (2016) Managing austerity: Comparing municipal austerity plans in the Netherlands and North Rhine Westphalia. Public Management Review 18: 1043-1062.

Paliokaitė A, Pačèsa N and Sarpong D (2014) Conceptualizing strategic foresight: An integrated framework. Strategic Change 23(3-4): 161-169.

Paliokaitè A and Pačèsa N (2015) The relationship between organisational foresight and organisational ambidexterity. Technological Forecasting and Social Change 101: 165181.

Papenfuß U, Saliterer I and Albrecht N (2017) A Cushioned Impact of the Financial Crisis Local Government Financial Resilience in Germany. In: Steccolini I, Jones M and Saliterer I (eds) Governmental Financial Resilience (Public Policy and Governance, Volume 27). Bingley: Emerald Publishing Limited, pp. 115-134.

Pauchant T and Mitroff I (1992) Transforming the crisis-prone organization. San Francisco: Jossey-Bass.

Pearson CM and Clair JA (1998) Reframing Crisis Management. The Academy of Management Review 23(1): 59-76.

Peters BG (2011) Governance Responses to the Fiscal Crisis - Comparative Perspectives. Public Money and Management 31(1): 75-80.

Pollitt C and Bouckaert G (2011) Public Management Reform: A Comparative Analysis - New Public Management, Governance, and the Neo-Weberian State. New York: Oxford University Press.

Raudla R, Savi R and Randma-Liiv T (2015) Cutback management literature in the 1970s and 1980s: taking stock. International Review of Administrative Sciences 81(3): 433-456.

Ray JL, Baker LT and Plowman DA (2011) Organizational mindfulness in business schools. Academy of Management Learning \& Education 10(2): 188-203.

Robbins G and Lapsley I (2014) The success story of the Eurozone crisis? Ireland's austerity measures. Public Money \& Management 34(2): 91-98. 
Robbins DK and Pearce JA II (1992) Turnaround: Retrenchment and recovery. Strategic Management Journal 13(4): 287-309.

Schendel D, Patton GR and Riggs J (1976) Corporate Turnaround Strategies: A Study of Profit Decline and Recovery. Journal of General Management 3(3): 3-11.

Shaw K (2012). The Rise of the Resilient Local Authority? Local Government Studies 38(3): 281-300.

Smart CF, Thompson WA and Vertinsky I (1978) Diagnosing Corporate Effectiveness and Susceptibility to Crises. Journal of Business Administration 9(2): 57-96.

Sohl S, Peddle MT, Thurmaier K, Wood CH and Kuhn G (2009) Measuring the financial position of municipalities: Numbers do not speak for themselves. Public Budgeting \& Finance 29(3): 74-96.

Somers S (2009) Measuring Resilience Potential: An Adaptive Strategy for Organizational Crisis Planning. Journal of Contingencies and Crisis Management 17(1): 12-23 .

Stephenson AV (2011) Benchmarking the resilience of organisations. PhD Thesis, University of Canterbury, New Zealand.

Steccolini I, Jones M and Saliterer I (eds) (2017) Governmental Financial Resilience: International Perspectives on how Local Governments Face Austerity. Bingley: Emerald Group Publishing.

Sutcliffe KM and Vogus TJ (2003) Organizing for resilience. In: Cameron KS, Dutton JE and Quinn RE (eds) Positive Organizational Scholarship: Foundations of a New Discipline. San Francisco: Berrett-Koehler.

Valentine S, Godkin L and Varca PE (2010) Role conflict, mindfulness, and organizational ethics in an education-based healthcare institution. Journal of Business Ethics 94(3): 455469.

Van de Ven AH and Ferry DL (1980) Measuring and assessing organizations. New York: John Wiley \& Sons.

Verbeeten FH (2008) Performance management practices in public sector organizations: Impact on performance. Accounting, Auditing \& Accountability Journal 21(3): 427-454.

Speklé RF and Verbeeten FH (2014) The use of performance measurement systems in the public sector: Effects on performance. Management Accounting Research 25(2): 131-146.

Van der Kolk B, Ter Bogt HJ and Van Veen-Dirks, PMG (2015) Constraining and facilitating management control in times of austerity Case studies in four municipal departments. Accounting, Auditing \& Accountability Journal 28(6): 934-965. 
Vogus TJ and Sutcliffe KM (2007) The Safety Organizing Scale: development and validation of a behavioral measure of safety culture in hospital nursing units. Medical Care 45(1): $46-54$.

Walker RM and Brewer GA (2009) Can management strategy minimize the impact of red tape on organizational performance? Administration \& Society 41(4): 423-448.

Wang XS (2014) Financial management in the public sector: tools, applications and cases. London: Routledge.

Weick KE (1979) The social psychology of organizing. 2nd edition. Reading, MA: AddisonWesley.

Weick KE and Sutcliffe KM (2001) Managing the Unexpected. San Francisco: Jossey-Bass.

Weick, KE, Sutcliffe KM, and Obstfeld D (2005) Organizing and the Process of Sensemaking Organization Science 16(4), pp. 409-421.

Whitman RZ, Kachali H, Roger D, Vargo J, and Seville E (2013) Short-form version of the Benchmark Resilience Tool (BRT-53). Measuring Business Excellence 17(3): 3-14.

Wicker P, Filo K and Cuskelly G (2013) Organizational resilience of community sport clubs impacted by natural disasters. Journal of Sport Management 27(6): 510-525.

Wildavsky AB (1988) The New Politics of the Budgetary Process. Glenview: Scott Foresman.

Wilson D and Game G (2011) Local Government in the United Kingdom. Hampshire: Palgrave Macmillan.

Youndt MA, Subramaniam M and Snell SA (2004) Intellectual capital profiles: An examination of investments and returns. Journal of Management Studies 41(2): 335-361. 
Figure 1: Analytical Framework

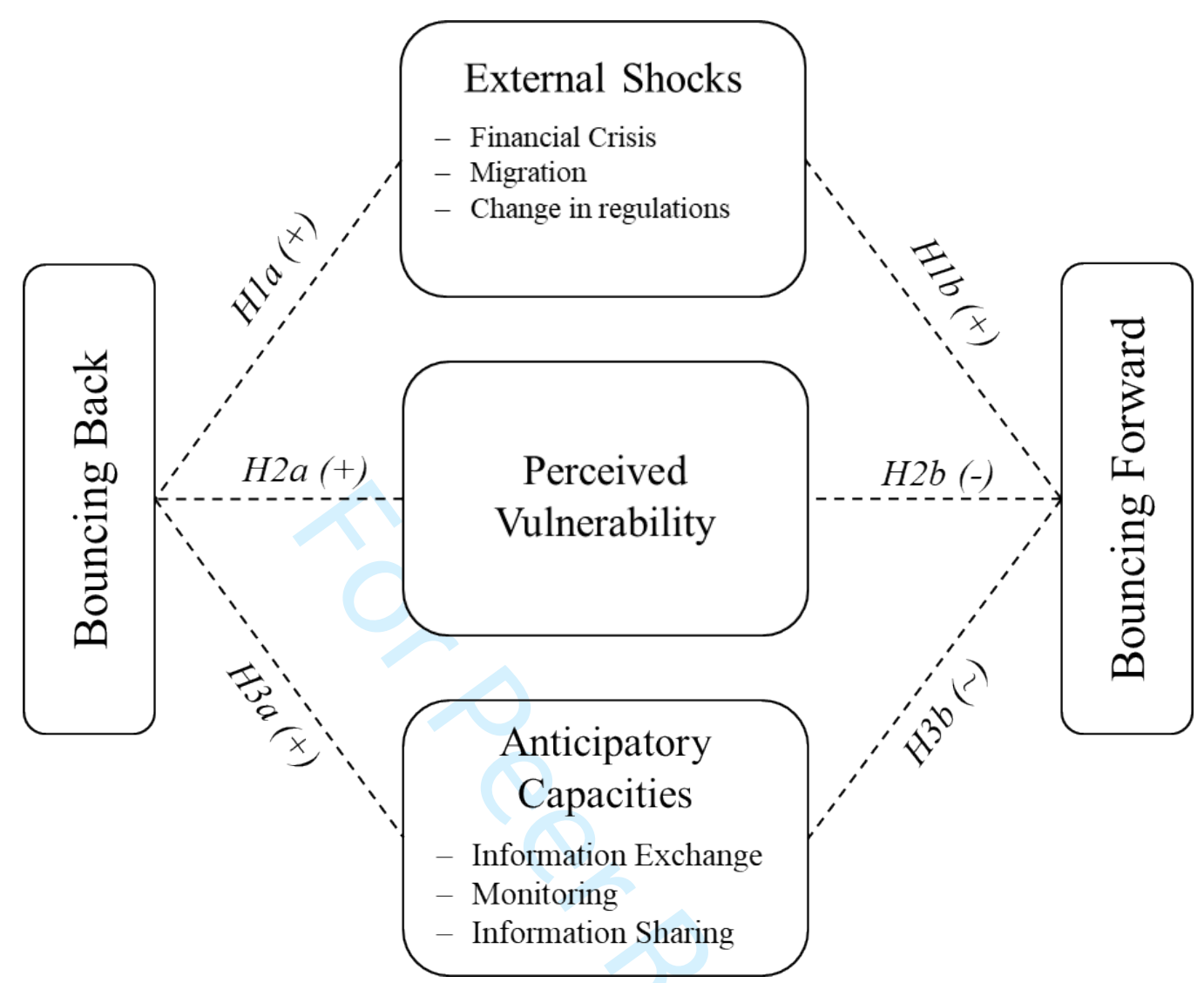


Table 1: Exploratory factor analysis response strategies (dependent variable)

All items were prefixed with: During the last 5 years, my local government.... $(1=$ not at all; $5=$ to a great extent $)$

Bouncing forward

St.

changed the way it delivers services

Mean

2.85

0.68

3.02

0.887

0.743

changed the priorities of traditional activities

2.88

0.920

0.709

changed its internal structure

3.07

1.079

0.544

extended its existing services

2.66

1.040

0.739

established new services

2.60

0.955

0.750

\section{Bouncing back}

2.37

0.69

reduced existing services

2.14

0.997

0.707

deferred/reduced investments

2.95

1.235

0.563

increased fees and charges for its services

2.69

1.005

0.654

liquidated assets in order to raise capital

2.21

1.062

0.542

eliminated some services

1.89

0.888

0.783

Eigenvalue

2.730

2.192

Explained Variance 
Table 2: Vulnerability and anticipatory capacities, descriptives and factor analysis

\begin{tabular}{|c|c|c|c|c|c|c|}
\hline \multirow[b]{3}{*}{ S Global Financial Crisis } & \multicolumn{2}{|c|}{ Descriptives } & \multicolumn{4}{|c|}{ Rotated Component Matrix } \\
\hline & Mean & Std. Dev & 1 & 2 & 3 & 4 \\
\hline & 3.26 & 1.126 & & & & \\
\hline S Migration & 2.58 & 1.064 & & & & \\
\hline S Regulations (e.g., changes in tax base, task devolvement) & 3.51 & 1.003 & & & & \\
\hline V Debt level & 2.43 & 1.33 & 0.753 & & & \\
\hline V Volatility of own-revenue sources & 3.00 & 0.99 & 0.857 & & & \\
\hline V Level of reserves & 3.04 & 1.15 & 0.837 & & & \\
\hline V Autonomy & 3.15 & 1.11 & 0.762 & & & \\
\hline AC Information exchange with other local governments & 3.66 & 0.86 & & 0.649 & & \\
\hline AC Information exchange with upper levels of government & 3.16 & 0.91 & & 0.689 & & \\
\hline AC Information exchange with external service providers & 2.93 & 0.91 & & 0.847 & & \\
\hline AC Regularly approach professional service providers & 2.91 & 1.00 & & 0.843 & & \\
\hline AC Monitoring changing national policies and regulations & 3.74 & 0.87 & & & 0.623 & \\
\hline AC Monitoring changing citizens' needs & 3.46 & 0.82 & & & 0.745 & \\
\hline AC Monitoring economic developments & 3.37 & 0.91 & & & 0.683 & \\
\hline AC Monitoring socio-demographic developments & 3.43 & 0.91 & & & 0.614 & \\
\hline AC People have the information and knowledge they need & 3.56 & 0.92 & & & & 0.797 \\
\hline AC Information is shared freely & 3.39 & 0.98 & & & & 0.548 \\
\hline AC Relevant information is passed on quickly & 3.56 & 0.98 & & & & 0.805 \\
\hline AC People are encouraged to conduct complete analysis of problems & 3.14 & 1.00 & & & & 0.680 \\
\hline Explained variance & & & 32.684 & 12.325 & 9.580 & 7.033 \\
\hline Eigenfaktor & & & 5.229 & 1.972 & 1.533 & 1.125 \\
\hline
\end{tabular}


Table 3: Results of regression analysis for response strategies

\begin{tabular}{|c|c|c|}
\hline & \multicolumn{2}{|c|}{ Response Strategies } \\
\hline & $\begin{array}{l}\text { Bouncing } \\
\text { Back }\end{array}$ & $\begin{array}{l}\text { Bouncing } \\
\text { Forward }\end{array}$ \\
\hline \multicolumn{3}{|l|}{ External Shocks } \\
\hline Global Financial Crisis & $.079 *$ & $.102 * *$ \\
\hline Migration & $.081 * *$ & $.160 * * *$ \\
\hline Regulations (e.g., changes in tax base) & $.146^{* * *}$ & $.112 * * *$ \\
\hline \multicolumn{3}{|l|}{ Anticipatory Capacities } \\
\hline Monitoring & -.025 & $.117 * *$ \\
\hline Information Exchange & -.004 & $.173 * * *$ \\
\hline Information Sharing & -.017 & $.080 *$ \\
\hline $\begin{array}{l}\text { Financial vulnerability } \\
\text { High level of (perceived) financial vulnerability }\end{array}$ & $.372 * * *$ & $-.129 * * *$ \\
\hline \multicolumn{3}{|l|}{ Controls } \\
\hline Size & .001 & -.014 \\
\hline Debt Ratio & -.007 & -.022 \\
\hline Investing Ratio & -.056 & -.007 \\
\hline Current Ratio & $-.132 * * *$ & $-.077 *$ \\
\hline Dummy UK & .051 & -.076 \\
\hline Dummy Italy & $-.106^{* *}$ & $-.165 * * *$ \\
\hline $\mathrm{R}^{2}$ & .285 & .201 \\
\hline Adjusted $\mathrm{R}^{2}$ & .270 & 0.184 \\
\hline $\mathrm{F}$ & 18.400 & 11.557 \\
\hline
\end{tabular}

Note: $* \mathrm{p}<0.1, * * \mathrm{p}<0.05$ and $* * * \mathrm{p}<0.01$ levels, respectively. 
Appendix 1a: Germany, Italy and UK: Main features

\begin{tabular}{|c|c|c|c|}
\hline & Germany & Italy & UK \\
\hline Population in 2013 & $80,523,746$ & $59,685,227$ & $63,905,297$ \\
\hline Administrative tradition & $\begin{array}{l}\text { Continental European } \\
\text { federal model }\end{array}$ & $\begin{array}{c}\text { Continental European } \\
\text { Napoleonic/Southern model }\end{array}$ & Anglo-Saxon model \\
\hline Level of decentralization & Federal & Unitary ("Quasi") & Unitary \\
\hline $\begin{array}{l}\text { Local government expenditure in \% of total government } \\
\text { expenditure (2013) }\end{array}$ & $16.3 \%$ & $28.6 \%$ & $25.1 \%$ \\
\hline \multicolumn{4}{|l|}{ No. of local governments (LAU 2 2013) } \\
\hline Population $>15,000$ & 961 & 737 & 416 \\
\hline Regional distribution of $L G>5,000$ & $\begin{array}{c}\text { Total: } 2,880 \\
\text { West: } 2,358 \\
\text { East: } 522\end{array}$ & $\begin{array}{c}\text { Total: } 2,411 \\
\text { North:1,592 } \\
\text { South:819 }\end{array}$ & $\begin{array}{c}\text { Total: } 417 \\
\\
\text { England: } 352 \\
\text { Scotland: } 32 \\
\text { Wales: } 22 \\
\text { Northern Ireland: } 11\end{array}$ \\
\hline
\end{tabular}


Appendix 1b: Germany, Italy and UK: Sample and respondents characteristics

\begin{tabular}{|c|c|c|c|}
\hline & Germany & Italy & UK \\
\hline \multicolumn{4}{|l|}{ Sample } \\
\hline Total & 1,921 & 1,574 & 406 \\
\hline Population 5,001-15,000 & 960 & 837 & 1 \\
\hline Population $>15,000$ & 961 & 737 & 405 \\
\hline Regional distribution of sample & $\begin{array}{c}\text { West: } 1,586 \\
\text { East: } 335\end{array}$ & $\begin{array}{l}\text { North: } 1,022 \\
\text { South: } 552\end{array}$ & $\begin{array}{l}\text { England: } 351 \\
\text { Scotland: } 32 \\
\text { Wales: } 22 \\
\end{array}$ \\
\hline \multicolumn{4}{|l|}{ Responding LGs } \\
\hline Total & $295(15 \%)$ & $268(17 \%)$ & $64(\%)$ \\
\hline Population 5,001-15,000 & $157(16 \%)$ & $133(16 \%)$ & -- \\
\hline Population $>15,000$ & $138(14 \%)$ & $135(18 \%)$ & $64(\%)$ \\
\hline Regional Distribution & $\begin{array}{c}\text { West: } 246(16 \%) \\
\text { East: } 49(15 \%)\end{array}$ & $\begin{array}{l}\text { North: } 200(20 \%) \\
\text { South: } 68(12 \%)\end{array}$ & $\begin{array}{c}\text { England: } 55(16 \%) \\
\text { Scotland: } 4(13 \%) \\
\text { Wales: } 5(23 \%) \\
\end{array}$ \\
\hline \multicolumn{4}{|l|}{ Respondent characteristics } \\
\hline Age (Median) & $51-55$ years & $51-55$ years & $51-55$ years \\
\hline$<35$ years & $5.6 \%$ & $1.2 \%$ & -- \\
\hline 36-45 years & $15.0 \%$ & $9.0 \%$ & $11.3 \%$ \\
\hline 46-55 years & $41.4 \%$ & $53.1 \%$ & $58.1 \%$ \\
\hline$>55$ years & $38.0 \%$ & $36.7 \%$ & $30.6 \%$ \\
\hline Gender (Male/Female) & $66.7 \% / 33.3 \%$ & $57 \% / 43 \%$ & $79 \% / 21 \%$ \\
\hline Education (College/University Degree) & $62.8 \%$ & $89.8 \%$ & $95.2 \%$ \\
\hline \multicolumn{4}{|l|}{ Tenure } \\
\hline$<10$ years & $26.3 \%$ & $7.0 \%$ & $8.1 \%$ \\
\hline $10-20$ years & $18.4 \%$ & $25.4 \%$ & $21.0 \%$ \\
\hline 20-30 years & $32.7 \%$ & $38.7 \%$ & $43.5 \%$ \\
\hline$>30$ years & $22.6 \%$ & $28.9 \%$ & $27.4 \%$ \\
\hline Private sector experience & $43.2 \%$ & $62.1 \%$ & $62.9 \%$ \\
\hline
\end{tabular}




\section{Appendix 2: Operationalization of variables}

\begin{tabular}{|c|c|c|}
\hline Dimension and definition & Operationalization (corresponding Variable in parentheses) & $\begin{array}{c}\text { Methods details and } \\
\text { references }\end{array}$ \\
\hline $\begin{array}{l}\text { Shocks/ Environmental Conditions } \\
\text { Environmental conditions comprise the } \\
\text { institutional, economic, and social environment in } \\
\text { which local governments operate. The focus of this } \\
\text { study is on external shocks that disrupt the } \\
\text { environmental conditions of local governments } \\
\text { thereby impacting their financial condition. }\end{array}$ & $\begin{array}{l}\text { Please indicate to what extent the following events negatively affected your local government's financial situation and } \\
\text { rate the impact it had. (1=not at all to } 5=\text { to a great extent) } \\
\text { Global Financial Crisis (Global Financial Crisis) } \\
\text { Migration (Migration) } \\
\text { Regulations (e.g. changes in tax base, task devolvement) (Regulations(e.g. changes in tax base, task devolvement)) }\end{array}$ & \begin{tabular}{|l|}
\end{tabular} \\
\hline $\begin{array}{l}\text { Vulnerability } \\
\text { The perceived extent of exposure to financial } \\
\text { shocks and disturbances that may affect local } \\
\text { government finances }\end{array}$ & $\begin{array}{l}\text { How would you rate the financial situation of your local government in terms of the following aspects? (1=strongly } \\
\text { disagree to } 5=\text { strongly agree) } \\
\text { Our local government is heavily indebted (Debt level) } \\
\text { The volatility of our own revenues sources (e.g. taxes) is high (Volatility of own revenues sources) } \\
\text { We have enough financial reserves (fiscal slack) to absorb a small amount of shock (Level of reserves) } \\
\text { Our financial autonomy (considering our own revenue sources) in general is high (Autonomy) }\end{array}$ & $\begin{array}{l}\text { Hendrick 2011, Maher and } \\
\text { Deller 2011, McManus et al. } \\
2007\end{array}$ \\
\hline $\begin{array}{l}\text { Anticipatory capacities } \\
\text { The availability of tools and capabilities that } \\
\text { enable local governments to better identify and } \\
\text { manage their vulnerabilities and to recognize } \\
\text { potential financial shocks before they arise, as } \\
\text { well as their nature, likelihood, timing, scale and } \\
\text { potential impacts. In this regard, anticipatory } \\
\text { capacity is not limited to the presence of systems } \\
\text { in place to plan, control, and manage risks, but } \\
\text { also related to situation awareness and sense- } \\
\text { making. }\end{array}$ & $\begin{array}{l}\text { Please indicate to what extent you agree/disagree to the following statements. In order to increase the understanding } \\
\text { about our environment... (1=strongly disagree to } 5=\text { strongly agree) } \\
\text { we regularly exchange information with other local governments } \\
\text { we regularly exchange information with upper levels of government } \\
\text { we regularly exchange information with external service providers } \\
\text { we regularly approach professional service providers such as consultants, or tax consultants/accountants } \\
\text { (External information exchange) } \\
\text { we constantly monitor changing national policies and regulations } \\
\text { we constantly monitor changing citizen's needs } \\
\text { we constantly monitor economic developments } \\
\text { we constantly monitor socio-demographic developments } \\
\text { (Monitoring) } \\
\text { Please indicate to what extent you agree/disagree to the following statements. In our local government...(1=strongly } \\
\text { disagree to 5=strongly agree) } \\
\text { it is considered important that people have the information and knowledge they need to respond to unexpected } \\
\text { problems that arise } \\
\text { information is shared freely across functions and hierarchical levels } \\
\text { when something unexpected happens, relevant information is passed on quickly across functions and hierarchical } \\
\text { levels } \\
\text { when something unexpected happens, people in this local government are encouraged to conduct a complete analysis } \\
\text { instead of providing routine solutions } \\
\text { (Internal information sharing) }\end{array}$ & $\begin{array}{l}\text { Amniattalab and Ansari 2016, } \\
\text { Boin et al. 2010, } \\
\text { Cohen and Levinthal 1990, } \\
\text { Jansen et. al. 2005, Jaworsky } \\
\text { and Kohli 1993, Jones 2105, } \\
\text { Lee et al. 2013, Lengnick- } \\
\text { Hall and Beck 2005, } \\
\text { Linnenluecke and Griffiths } \\
\text { 2013, McManus et al. 2007, } \\
\text { Mott 1972, Paliokaite and } \\
\text { Pacesa 2015, Ray et al. 2011, } \\
\text { Somers 2009, Stephenson } \\
\text { 2011, Weick and Sutcliffe } \\
\text { 2001, 2006, Whitman et al. } \\
\text { 2013, Wicker et al. 2013, } \\
\text { Youndt et. al. 2004 }\end{array}$ \\
\hline
\end{tabular}


Operationalization (corresponding Variable in parentheses)

Response strategies

The ability to deal with the impact of shocks and disturbances, becoming visible in times of

disruption (shock) through strategies, reflecting,

on the one hand, the capability to bounce back to

an original state or, on the other hand, the ability

to, bounce forward through the enhancement of,

or development of new, capabilities emphasizing

or developity to reorganize as a response to, on

the capacity to reorganize as a response to, or in

anticipation of, disturbances, alter or reinvent

their strategies

During the last 5 years, my local government...(1=not at all to $5=$ to a great extent $)$

reduced existing services

deferred/reduced investments

increased fees and charges for its services

liquidated assets in order to raise capital

eliminated some services

\section{(Bouncing back)}

changed the way it delivers services

changed the priorities of traditional activities

changed its internal structure

extended its existing services

established new services

(Bouncing forward)

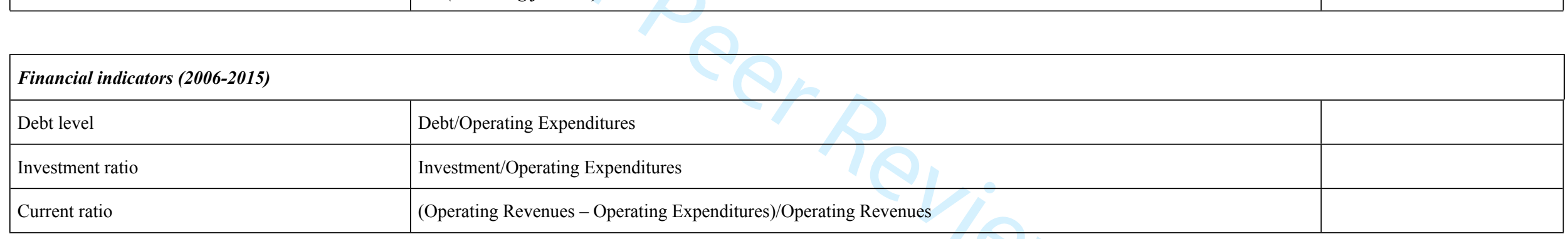

